\title{
First report of branch canker on Chinese date caused by Diplodia mutila in China
}

\author{
Huijing Feng ${ }^{1} \cdot$ Kunqi Hong ${ }^{1} \cdot$ Huijun $\mathrm{Xi}^{1} \cdot$ Lulu Song $^{1} \cdot$ Caiyi Wen ${ }^{1} \cdot$ Rui Zang $^{1}$ (D)
}

Received: 27 November 2018 / Accepted: 30 April 2019/Published online: 1 August 2019

(C) Società Italiana di Patologia Vegetale (S.I.Pa.V.) 2019

Keywords Chinese date $\cdot$ rDNA-ITS $\cdot$ EF1 $\alpha \cdot \beta$-tubulin $\cdot$ Diplodia mutila

Chinese date branch canker is an important disease on Ziziphus jujuba Mill in China. Cankers were first observed in 1998 on trees in Jiaocheng County, Shanxi province, where the climate was dry. The cankers were dark brown, sunken and crinkled, and mainly occurred on scaffolds, twigs and deciduous spurs. The tissue samples from the diseased and healthy boundaries were surface sterilized with $75 \%$ ethyl alcohol and rinsed with sterile distilled water. The tissue samples were placed on potato dextrose agar amended with $50 \mu \mathrm{g} / \mathrm{ml}$ cephalosporin and incubated in the dark at $25^{\circ} \mathrm{C}$. The cultures grew fast, and colonies varied in color from white in the earlier stages, to black in the later period. The pycnidia were induced to form on $2 \%$ water agar media added by pine needles. The pycnidia were black and very tiny. Conidia were initially hyaline, ellipsoid, thin-walled, unicellular, becoming two-celled and dark brown at maturity. The spores measured 20.08 to $28.42 \times 9.58$ to $15.51 \mu \mathrm{m}$ by measuring fifty spores. For molecular confirmation, the complete rDNA-ITS sequence and the partial sequences of EF1 $\alpha$ and $\beta$-tubulin of one representative isolate LLAJZ009 were amplified using primer pairs ITS1/ITS4, EF1-728F/EF1-986R and Bt2a/Bt2b, respectively (Úrbez-Torres et al. 2013). The ITS

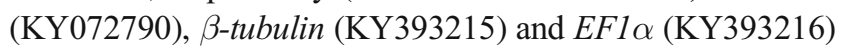
sequences had been deposited in GenBank. The maximum parsimony tree combined the three genes sequences revealed the isolate claded with $D$. mutila representative isolate CBS112533 and CBS230.30 with 92\% bootstrap support. Thus, the isolate was identified as D. mutila according to these results (Liu et al. 2012). Pathogenicity tests were conducted on two-year-old lateral branches. The lateral branches were

Rui Zang

zangxirui@163.com

1 College of Plant Protection, Henan Agricultural University, Zhengzhou 450002, Henan, China wounded by removing a piece of bark with a sterile scalpel and a $5 \mathrm{~mm}$ fresh mycelial plugs were placed on the wounds. The tips of the inoculated branch wilt and some tiny pycnidia appeared around the inoculated site. The lesions expand to 65$97 \mathrm{~mm}$ at 35 days post inoculation, while no obvious lesions appeared on the controls. The pathogen was re-isolated from all inoculated branches and no obtained from the controls. Canker diseases caused by D. mutila have been reported on apple (Úrbez-Torres et al. 2016) and olive (Úrbez-Torres et al. 2013). To our knowledge, this is the first report of the canker disease caused by Diplodia mutila on Chinese date in China.

Acknowledgments This study was supported by the National Natural Science Foundation for Yong Scientists of China (No. 31301609).

\section{Compliance with ethical standards}

Animal studies This article does not contain any studies with human participants or animals performed by any of the authors.

Informed consent Informed consent was obtained from all individual participants included in the study.

\section{References}

Liu JK, Phookamsak R, Doilom M, Wikee S, L YM, Ariyawansha H, Boonmee S, Chomnunti P, Dai DQ, Bhat JD, Romero AI, Zhuang WY, Mohkai J, Gareth EB, Chukeatirote E, Koko TW, Zhao YC, Wang Y, Hyde KD (2012) Towards a natural classification of Botryosphaeriales. Fungal Divers 57:149-210

Úrbez-Torres JR, Peduto F, Vossen PM, Krueger WH, Gubler WD (2013) Olive twig and branch dieback: etiology, incidence, and distribution in California. Plant Dis 97:231-244

Úrbez-Torres JR, Boulé J, O'Gorman DT (2016) First report of Diplodia seriata and D.mutila causing apple dieback in British Columbia. Plant Dis 100:1243

Publisher's note Springer Nature remains neutral with regard to jurisdictional claims in published maps and institutional affiliations. 